\title{
MEDIASI IN COURT UNTUK MEWUJUDKAN KEPASTIAN HUKUM BERDASARKAN WIN - WIN SOLUTION
}

Anita Afriana

Fakultas Hukum Universitas Padjadjaran

Email : anita.afriana@unpad.ac.id; nie782003@yahoo.com

\begin{abstract}
ABSTRAK
Pada dasarnya, sama dengan penyelesaian perdata di Pengadilan Negeri, perdamaian dalam penyelesaian kasus kebangkrutan wajib dilaksanakan. Pasal 130 HIR / 154 HIR tentang kewajiban untuk merekonsiliasi kedua belah pihak telah dilakukan melalui Perma No 1, tahun 2016. Namun, Perma ini tidak dapat diterapkan untuk penyelesaian kasus kebangkrutan di Pengadilan Niaga. Penelitian ini ingin mengetahui alasan yuridis perdamaian yang dicapai melalui Mediasi di Pengadilan berdasarkan Perma no. 1 tahun 2016 tidak dapat diterapkan dalam penyelesaian perselisihan kebangkrutan di Pengadilan Niaga dan konsekuensi yuridis yang membedakan antara perdamaian yang dicapai melalui mediasi di Pengadilan dan proses kebangkrutan dan PKPU yang berkaitan dengan kepastian sebagai tujuan undang-undang.

Perdamaian di Perma No1 tahun 2016 yang diupayakan dengan cara mediasi tidak dapat diterapkan pada kasus kebangkrutan karena kebangkrutan termasuk dalam ranah relawan sedangkan mediasi di pengadilan diimplementasikan dalam kasus contentiosa. Oleh karena itu, perdamaian dalam penyelesaian kasus kebangkrutan tidak dapat dilaksanakan pada awal penyidikan kasus kebangkrutan di Pengadilan Niaga, karena perdamaian baru dapat diterapkan jika status debitur jelas sebagai partai bangkrut. Meskipun mediasi tidak dapat dilaksanakan untuk mencapai kedamaian dalam kasus kebangkrutan di Pengadilan Niaga, konsep solusi win-win tetap dalam pelaksanaan perdamaian di Pengadilan Niaga adalah sebuah perdamaian yang dapat memberikan manfaat yang seimbang bagi kedua belah pihak. sebagai pelaku usaha.
\end{abstract}

Kata kunci: kebangkrutan, perdamaian, win-win Solution

\section{ABSTRACT}

Basically, same with the civil settlement in the District Court, peace in the settlement of bankruptcy cases is required to be implemented. The article of 130 of HIR / 154 HIR concerning the obligation to reconcile the two sides have been concreted through Perma No 1, year 2016. However, this Perma can't be 
applied to the settlement of bankruptcy cases in the Commercial Court. This study want to know the juridical reasons the peace achieved through Mediation In Court based on Perma no. 1 of 2016 can't be applied in the settlement of bankruptcy disputes in the Commercial Court and the juridical consequences that distinguish between the peace achieved through mediation in Court and the bankruptcy proceedings and PKPU related to certainty as the purpose of law

Peace institutions through Perma No1, year 2016 pursued by means of mediation can not be applied to bankruptcy cases because bankruptcy is included in the volunteer domain whereas mediation in court is implemented in contentiosa case. Therefore, peace in the settlement of bankruptcy cases can't be executed at the beginning of the investigation of bankruptcy cases in the Commercial Court, as new peace can be applied if the debtor's status is clear as a bankrupt party. Although mediation can't be implemented in order to achieve peace in the bankruptcy case in the Commercial Court, the concept of a win-win solution remains in the implementation of peace in the Commercial Court is a peace that can provide balanced benefits for both parties as business actors.

Keywords: bankruptcy, peace, win-win Solution

\section{PENDAHULUAN}

Pada dasarnya, sepanjang masalah yang timbul tidak termasuk kriminal, maka perselisihan tidak harus bermuara di pengadilan. Secara garis besar, terdapat 2 macam cara untuk menyelesaikan perselisihan, yakni adjudikasi dan non-adjudikasi. Yang termasuk adjudikasi diantaranya adalah pengadilan (litigasi) dan arbitrase, sedangkan non-adjudikasi antara lain adalah mediasi, negosiasi dan konsiliasi.

Perbedaan mendasar pada 2 penggolongan itu adalah bahwa di dalam adjudikasi terdapat pihak ketiga yang berfungsi untuk memutus (perkara). Dalam hal ini, proses litigasi diputus oleh hakim dan pada arbitrase, putusan diambil oleh seorang arbiter. Sedangkan penyelesaian perkara dengan cara non-adjudikasi, segala sesuatunya ditentukan atau disepakati oleh para pihak yang berselisih. Kalau pun ada pihak ketiga dalam proses penyelesaian perkaranya seperti pada mediasi misalnya, pihak ketiga tidak memiliki otoritas untuk memutus. 
Salah satu cara yang dilakukan untuk mengatasi penumpukan perkara adalah melalui mediasi. Mediasi pada prinsipnya merupakan salah satu bentuk dari alternatif penyelesaian sengketa (Alternative Dispute Resolution) berdasarkan UU No. 30 Tahun $1999^{1}$. Dikatakan sebagai alternatif penyelesaian sengketa karena mediasi merupakan satu alternatif penyelesaian sengketa di samping pengadilan. Panjangnya proses peradilan, mulai dari tingkat pengadilan pertama, banding, kasasi dan peninjauan kembali (PK) membuat penyelesaian membutuhkan waktu yang lama padahal masyarakat mencari proses penyelesaian yang mudah dan cepat. Dalam kenyataannya, sampai saat ini belum ada yang mampu mendesain sistem peradilan yang efektif dan efisien. Lembaga sejenis mediasi untuk menyelesaikan perkara di luar pengadilan sudah diatur dalam Pasal 130 HIR/154 RBg. Pasal ini menyatakan bahwa bila kedua belah pihak hadir di pengadilan, maka hakim akan mencoba mendamaikan mereka. Bila perdamaian tercapai, maka dibuatkan akta perdamaian ( acta van dading) yang harus dipatuhi, berkekuatan dan dijalankan sebagai keputusan biasa.

Selain landasan formil yang diatur dalam HIR/RBg, sebenarnya MA telah mengintegrasikan mediasi ke dalam sistem peradilan ke arah yang lebih bersifat memaksa. Awalnya, MA mengeluarkan SEMA No. 1 Tahun 2002 tentang Pemberdayaan Pengadilan Tingkat Pertama untuk menerapkan lembaga damai. Namun, dirasakan keberadaan SEMA ini tidak jauh berbeda dengan ketentuan dalam Pasal 130 HIR. Kemudian, MA melakukan penyempurnaan dengan mengeluarkan PERMA No. 2 Tahun 2003 Tentang Prosedur Mediasi di Pengadilan.

Pemilihan proses mediasi sebagai penyelesaian sengketa pada dasarnya tidak hanya disebabkan oleh biaya yang lebih murah dibandingkan dengan berperkara melalui pengadilan. Proses mediasi berjalan dengan 2 prinsip yang penting Pertama, adanya prinsip win-win solution, bukan win-lose 
solution. Di sini, para pihak sama-sama menang tidak saja dalam arti ekonomi atau keuangan, melainkan termasuk juga kemenangan moril dan reputasi ( nama baik dan kepercayaan). Kedua, mediasi memiliki prinsip bahwa putusan tidak mengutamakan pertimbangan dan alasan hukum, melainkan atas dasar kesejajaran kepatutan dan rasa keadilan, sehingga dapat disimpulkan bahwa proses perdamaian melalui mediator sangat penting dan wajib dilakukan dalam setiap proses penyelesaian sengketa perdata di pengadilan.

Selaras dengan perdamaian yang dicapai melalui mediasi, dalam penyelesaian sengketa perdata, dikenal pula istilah perdamaian (accord) dalam penyelesaian kepailitan maupun penundaan kewajiban pembayaran utang (PKPU) di Pengadilan Niaga.

Kepailitan digambarkan sebagai suatu keadaan pihak yang dinyatajakn pailit tidak memiliki kekuasaan / kemampuan lagi untuk mengelola kekayaannya yang dinyatakan pailit yang disebabkan karena harta kekayaan yang dimilikinya sudah tidak cukup untuk melunasi hutang beberapa kreditor ${ }^{2}$.

Rencana perdamaian adalah perjanjian antara Debitor dan para Kreditornya mengenai penyesuian jumlah piutang (yang diajukan Kreditor) dengan jumlah utang yang diajukan Debitor, dalam rangka menghindari terjadinya likuidasi. Perjanjian perdamaian dapat diajukan dalam perkara kepailitan maupun perkara PKPU. Perjanjian tersebut harus disetujui oleh para Kreditor konkuren dengan melakukan pemungutan suara dalam rapat Kreditor, dan untuk beberapa kriteria juga harus disetujui oleh pengadilan. Jika disetujui, maka akan mengikat seluruh Kreditor Konkuren, dan bila Kreditor atau pengadilan menolak rencana perdamaian, maka Debitor akan dilikuidasi

Dalam rencana perdamaian, Debitor atau Kurator akan menawarkan pembayaran yang lebih besar jika dibandingkan dengan pembayaran yang

2 Imran Nating, Peranan dan tanggung Jawab Kurator dalam Pengurusan dan Pemberesan Harta Pailit, PT. Raja Grafindo Persada, cet 1, Jakarta, 2004, hlm 190. 
didapat melalui proses likuidasi, tapi dengan jangka waktu yang lebih lama. Selama masa waktu tersebut, dapat saja terjadi sesuatu hal yang buruk terhadap perusahaan Debitor dan rencana perdamaian menjadi gagal. Jika hal tersebut terjadi, maka Kreditor Konkuren kemungkinan akan dibayar lebih rendah lagi.

Perdamaian (Accord) merupakan upaya yang dilakukan Debitor dengan para Kreditor Konkuren dapat digunakan sebagai sarana dan upaya untuk menyelesaian kredit macet karena tujuan utama dari perdamaian dengan rekstrukturisasi utang adalah memberi kesempatan kepada Debitor untuk dapat terus berusaha dengan tenang, sehingga Debitor dapat melunasi utangutangnya dan terlindar dari pailit. Perdamain merupakan salah satu mata rantai dalam proses penundaan kewajiban pembayaran utang. Pada prinsipnya perdamaian merupakan "kata sepakat" antara para pihak yang beritikad untuk mencari kedailan, jalan terbaik bagi para pihak (win-win solution) hak melindungi hak-hak para pihak yang bertikai yaitu Debitor dan Kreditor.

Pada prinsipnya, perdamaian (accord) berbeda dengan perdamaian dalam lapangan hukum perdata secara umum, karena perdamaian dalam kepailitan dan PKPU bukan untuk mengakhiri atau mencegah sengketa, sehingga dapat ditafsirkan pula keberadaan Mediasi in court tidak dapat diterapkan dalam penyelesaian sengketa kepailitan sebagaimana amanat ketentuan Pasal 4 ayat (1) dan (2) PERMA No. 1 Tahun 2016 yang berbunyi :

“ Semua sengketa perdata yang diajukan ke pengadilan termasuk perkara perlawanan ( verzet) atas putusan verstek dan perlawanan pihak berperkara ( partij verzet) maupun pihak ketiga ( derden verzet) terhadap pelaksanaan putusan yang telah berkekuataan hukum tetap, wajib terlebih dahulu diupayakan penyelesaian melalui 
mediasi, kecuali ditentukan lain berdasarkan Peraturan Mahkamah Agung ini.

\section{Pasal 2:}

Sengketa yang dikecualiakan dari kewajiban penyelesaian melalui mediasi sebagaimana dimaksud pada ayat (1) meliputi:

(1) Sengketa yang diselesaikan melalui prosedur Pengadilan Niaga

Berdasarkan pemaparan dari 2 ketentuan di atas, dapat disimpulkan bahwa semua perkara perdata wajib untuk lebih dahulu diselesaikan melalui perdamaian dengan bantuan mediator. Atas dasar uraian tersebut, mendorong penulis untuk meneliti mengenai eksistensi perdamaian (accord) dalam peenyelesaian sengketa pailit, dan menjadi tema yang sangat menarik untuk diteliti karena Kedudukan Pengadilan Niaga merupakan pengadilan tingkat pertama yang pada prinsipnya menyelesaiakan sengketa perdata, namun pelaksanaan mediasi in Court berdasarkan Perma No. 1 Tahun 2016 untuk mencapai perdamaian tidak dapat diterapkan pada penyelesaian sengketa kepailitan di Pengadilan Niaga. Oleh karenanya yang menjadi rumusan masalah untuk dikaji lebih lanjut yaitu : Mengapa perdamaian yang dicapai melalui Mediasi In Court berdasarkan Perma No. 1 Tahun 2016 tidak dapat diterapkan dalam penyelesaian sengketa pailit di Pengadilan Niaga? serta bagaimana konsekuensi yuridis yang membedakan antara perdamaian yang dicapai melalui mediasi in Court dan perdamaian (accord) dalam perkara pailit dan PKPU terkait dengan kepastian sebagai tujuan hukum?

Penulisan artikel ini berdasarkan hasil penelitian. Penelitian telah dilakukan dengan metode yuridis normatif dengan spesifikasi deskriptif analitis. Data didapatkan melalui studi kepustakaan untuk mendapatkan data sekunder, sementara data primer didapatkan dengan melakukan wawancara 
dengan praktisi hukum di Pengadilan Niaga Jakarta Pusat untuk selanjutnya dianalisis dengan mtode yuridis kualitatif.

\section{PEMBAHASAN}

Perdamaian Melalui Mediasi In Court Berdasarkan Perma No. 1 Tahun 2016 Tidak Dapat diterapkan Dalam Penyelesaian Sengketa Pailit di Pengadilan Niaga

Undang-undang No. 48 Tahun 2009 Tentang Kekuasaan Kehakiman menyatakan bahwa penyelesaian sengketa di pengadilan harus berdasarkan asas cepat, sederhana, dan biaya ringan. Asas ini lalu dikonkretkan melalui Surat Edaran Mahkamah Agung No. 6 Tahun 1992 yang menghimbau untuk menyelesaikan sengketa pada tingkat Pengadilan Negeri dan Pengadilan Tinggi diputuskan dalam waktu 60 hari. Asas ini tidak selalu terlaksana dalam praktiknya, karena banyak factor penyebabnya seperti para pihak tang tidak pernah datang, pemanggilan para pihak dan saksi yang berada diluar wilayah hukum pengadilan negeri tempat bersidang sehingga diperlukan upaya delegasi merupakan salah satu kendala yang menyebabkan jalannya persidangan mengulur waktu.

Pada pemeriksaan perkara di pengadilan, tahap awal dilakukan upaya perdamaian/dading terlebih dahulu. Menurut Pasal 130 HIR/154 RBg, hakim haruslah berupaya mendamaikan kedua belah pihak yang bersengketa karena melalui perdamaian dipandang cukup efektif untuk menekan penumpukan perkara di pengadilan karena perkara tidak berlanjut ke tahap selanjutnya. Namun dalam praktik di pengadilan, hanya dipandang sebagai akan dibuatkan akta perdamaian tersebut oleh hakim. Sebaliknya apabila mediasi tidak menghasilkan kesepakatan penyelesaian sengketa secara damai, maka proses pemeriksaan persidangan akan berlanjut sesuai tahapan mulai jawab menjawab hingga putusan yang bersifat win lose solution. 
Untuk mengejahwantahkan Pasal 130 HIR/154 RBg tersebut, maka sejak tahun 2008 dikeluarkan Perma No. 1 Tahun 2008 Tentang Prosedur Mediasi di Pengadilan dan selanjutnya Perma No. 1 Tahun 2016. Mediasi dipandang sebagai bagian dari proses perkara karena dilakukan pada awal proses persidangan. Untuk mengkonkretkan Pasal 130 HIR/154 RBg, maka mediasi dilakukan pada awal proses persidangan yang apabila sengketa selesai secara damai maka pertama dilingkungan Peradilan Umum dan Peradilan Agama, atas dasar kesepakatan, upaya perdamaian dapat ditempuh juga terhadap perkara yang sedang dalam proses banding, kasasi, atau peninjauan kembali, atau perkara yang diperiksa pada tingkat banding, kasasi, dan peninjauan kembali sepanjang perkara tersebut belum diputus.

Dengan adanya Perma No. 1 Tahun 2016 diharapkan seluruh pengadilan negeri di Indonesia telah melaksanakan proses mediasi terhadap penanganan seluruh perkara perdata yang masuk untuk diadili

Dapat disimpulkan dari Pasal 3 ayat (2) Perma No. 1 Tahun 2016, bahwa dalam pertimbangan dan putusan hakim, harus selalu dicantumkan adanya uraian bahwa sesungguhnya perkara yang diputus tersebut sebelumnya telah diupayakan perdamaian namun tidak berhasil, karena adanya kelalaian untuk mendamaikan mengakibatnya putusan tersebut dianggap tidak pernah ada. Melalui Pasal 2 ayat (1) dan ayat (2), pemerintah hanya mewajibkan proses mendamaikan ini dilakukan dan ditempuh pada ranah pengadilan negeri dan pengadilan agama saja. Dikenal adanya pengadilan khusus yang juga berada pada lingkungan pengadilan negeri, namun tidak terikat/terlepas dari ketentuan Perma No. 1 Tahun 2016.

Perkara kepailitan merupakan perkara perdata yang terjadi karena adanya Debitor yang memiliki hutang yang telah jatuh waktu dan dapat ditagih kepada 2 atau lebih Kreditor. Oleh karena itu pada prinsipnya seluruh tahapan beracara perdata diberlakukan pada penyelesaian perkara kepailitan, kecuali hal hal yang telah diatur dalam UUKPKPU secara khusus. 
Istilah perdamaian dikenal dalam UUKPKPU, namun PERMA No. 1 Tahun 2016 mengecualikan Pengadilan Niaga untuk menempuh proses mediasi yang tujuannya untuk mencapai perdamaian. Pada dasarnya, sama halnya seperti penyelesaian perkara perdata pada umumnya di Pengadilan Negeri, perdamaian dalam penyelesaian perkara pailit pun diwajibkan untuk dilaksanakan. Hal ini sesuai dengan Pasal 144 Undang-Undang No. 37 tahun 2007 tentang Kepailitan yang berbunyi "Debitor Pailit berhak untuk menawarkan suatu perdamaian kepada semua Kreditor". Pandangan tentang eksistensi perdamaian dalam penyelesaian sengketa pailit pada pengadilan Niaga ini, mungkin sedikit dikacaukan dengan Pasal 4 ayat (2) PERMA No. 1 Tahun 2016 yang pada intinya menyatakan bahwa perdamaian melalui mediasi tidak berlaku di Pengadilan Niaga. Keberadaan hal inilah yang membuat seolah-olah perdamaian itu sendiri tidak wajib dilaksanakan dalam penyelesaian perkara pailit di Pengadilan Niaga. Padahal sebenarnya, yang perlu kita garis bawahi dalam hal ini bahwa yang tidak wajib dilaksanakan dalam penyelesaian perkara pailit di pengadilan niaga itu adalah mediasi, bukan perdamaiannya ${ }^{3}$.

Kedudukan perdamaian sendiri dalam Pengadilan Niaga khususnya dalam penyelesaian perkara pailit tetap wajib dilaksanakan, akan tetapi prosedurnya tidak melalui mediasi. Mediasi tidak dapat diterapkan dalam perkara kepailitan, karena jenis perkaranya berbeda dengan perkara perdata pada umumnya. Perkara yang dapat didamaikan melalui proses mediasi adalah perkara contentiosa (mengandung sengketa), sedangkan perkara volunteer (tidak mengandung sengketa) seperti perkara kepailitan ini tidak dapat diselesaikan dengan mediasi.

Dalam penyelesaian perkara pailit di Pengadilan Niaga, hakim pengawas wajib menganjurkan dan menjelaskan kepada debitor tentang pengajuan rencana perdamaian, karena jika tidak diajukan ren cana perdamaian oleh debitor, maka demi hukum harta pailit dalam keadaan insolvensi (tidak mampu membayar). Jadi, pada pokoknya keberadaan perdamaian dalam

${ }^{3}$ Wawancara dengan Parwoto Wignjosumarto di Pengadilan, Hakim Niaga Jakarta pada Tahun 1998-1999 semula Direktur Perdata Niaga pada mahkamah tahun 2001, Hakim tinggi pada Pengadilan Tinggi DKI Jakarta.. 
penyelesaian perkara pailit di Pengadilan Niaga dengan perdamaian pada penyelesaian perkara perdata pada umumnya di pengadilan Negeri itu sama-sama diwajibkan, akan tetapi langkah-langkah, letak dan prosedurnyalah yang membedakan. Salah satu contohnya tadi, dalam penyelesaian perkara pailit, perdamaiannya tidak dilaksanakan melalui mediasi. Secara keseluruhan, ada beberapa hal yang membedakan perdamaian dalam penyelesaian perkara pailit di Pengadilan Niaga dengan perdamaian pada penyelesaian perkara perdata pada umumnya di pengadilan Negeri, yaitu :

\begin{tabular}{|c|c|c|c|}
\hline No. & $\begin{array}{c}\text { Unsur Yang } \\
\text { Membedakan }\end{array}$ & $\begin{array}{c}\text { Perdamaian Pada } \\
\text { Penyelesaian Perkara } \\
\text { Perdata Pada Umumnya Di } \\
\text { Pengadilan Negeri }\end{array}$ & $\begin{array}{c}\text { Perdamaian Dalam } \\
\text { Penyelesaian Perkara Pailit } \\
\text { Di Pengadilan Niaga }\end{array}$ \\
\hline 1. & Subjek Hukum & $\begin{array}{l}\text { Dalam penyelesaian perkara } \\
\text { perdata di Pengadilan Negeri, } \\
\text { yang aktif dalam mendorong } \\
\text { perdamaian antara para } \\
\text { pihak adalah hakimnya, hal } \\
\text { ini sesuai dengan Pasal } 130 \\
\text { HIR, yang menjadi dasar yang } \\
\text { mewajibkan hakim untuk } \\
\text { mendamaikan para pihak. } \\
\text { Jika hakim tidak } \\
\text { melaksanakan kewajibannya } \\
\text { tersebut, maka putusannya } \\
\text { batal demi hukum. }\end{array}$ & $\begin{array}{l}\text { Dalam perkara kepailitan, } \\
\text { yang aktif dalam menggagas } \\
\text { perdamaian yang akan } \\
\text { dilaksanakan adalah } \\
\text { pemohon / debitur } \\
\text { pailitnya sendiri. }\end{array}$ \\
\hline 2. & $\begin{array}{l}\text { Waktu } \\
\text { Pelaksanaan } \\
\text { Proses } \\
\text { Perdamaian }\end{array}$ & $\begin{array}{l}\text { Perdamaian dalam hal ini } \\
\text { dilaksanakan sebelum hakim } \\
\text { memeriksa pokok } \\
\text { terutama }\end{array}$ & $\begin{array}{l}\text { Perdamaian dalam hal ini } \\
\text { dilaksanakan setelah ada } \\
\text { putusan atas permohonan } \\
\text { pernyataan pailit, tepatnya }\end{array}$ \\
\hline
\end{tabular}




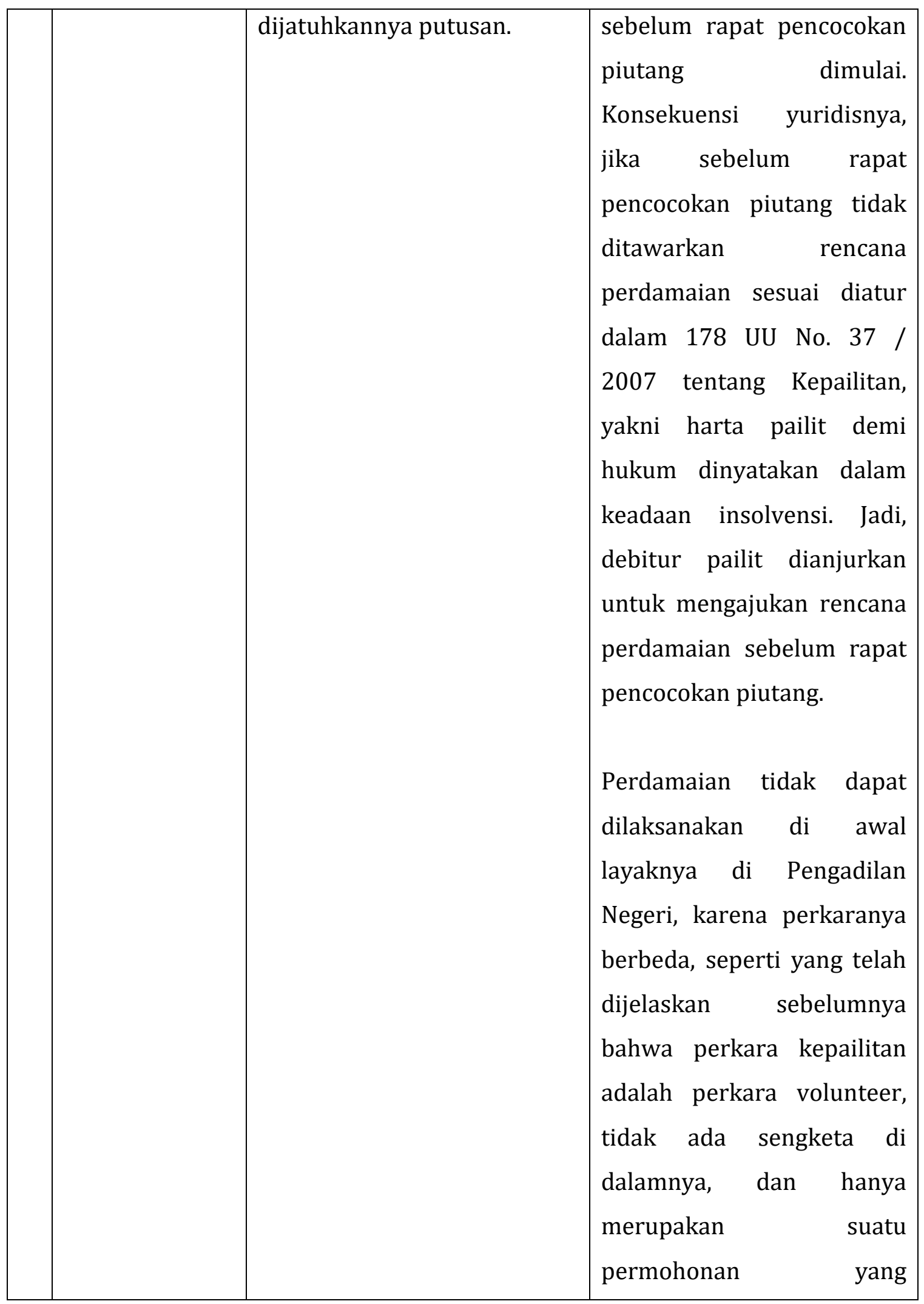




\begin{tabular}{|c|c|c|c|}
\hline & & & $\begin{array}{l}\text { putusannya pun bersifat } \\
\text { menyatakan suatu keadaan } \\
\text { / status kepailitan dari } \\
\text { debitur, oleh karenanya } \\
\text { perdamaian dalam hal ini } \\
\text { baru dapat dilaksanakan } \\
\text { setelah dinyatakan terlebih } \\
\text { dahulu bahwa debitur pailit. } \\
\text { Jika dilaksanakan di awal, } \\
\text { maka tujuan dari } \\
\text { perdamaian itu sendiri } \\
\text { tidak jelas karena status } \\
\text { pailit / tidaknya debitur } \\
\text { pun belum dapat } \\
\text { ditentukan. }\end{array}$ \\
\hline 3. & $\begin{array}{l}\text { Pelaksaan } \\
\text { Perdamaian }\end{array}$ & $\begin{array}{l}\text { Di Pengadilan Negeri, secara } \\
\text { umum perdamaian dapat } \\
\text { dilaksanakan sendiri oleh } \\
\text { para pihak baik di luar } \\
\text { pengadilan maupun di dalam } \\
\text { pengadilan melalui bantuan } \\
\text { mediator dalam proses } \\
\text { mediasi. }\end{array}$ & $\begin{array}{l}\text { Pada penyelesaian perkara } \\
\text { pailit di Pengadilan Niaga, } \\
\text { perdamaian dilaksanakan } \\
\text { dengan dipimpin oleh } \\
\text { hakim pengawas. }\end{array}$ \\
\hline 4. & $\begin{array}{l}\text { Pihak } \\
\text { Pelaksana } \\
\text { Perdamaian }\end{array}$ & $\begin{array}{l}\text { Tergugat dan Penggugat atau } \\
1 \text { (satu) debitur dan } 1 \text { (satu) } \\
\text { kreditur. }\end{array}$ & $\begin{array}{l}\text { Debitur bersama dengan } \\
\text { seluruh kreditur (lebih dari } \\
\text { dua). }\end{array}$ \\
\hline 5. & $\begin{array}{l}\text { Persetujuan } \\
\text { Perdamaian }\end{array}$ & $\begin{array}{l}\text { Dalam mencapai perdamaian } \\
\text { dibutuhkan persetujuan } \\
\text { antara para pihak yang }\end{array}$ & $\begin{array}{lr}\text { Dalam mencapai } \\
\text { perdamaian, maka } \\
\text { diperlukan persetujuan atas }\end{array}$ \\
\hline
\end{tabular}




\begin{tabular}{|l|l|l|}
\hline & $\begin{array}{l}\text { bersengketa yakni Penggugat } \\
\text { dan Tergugat. }\end{array}$ & $\begin{array}{l}\text { dasar pemungutan suara di } \\
\text { antara seluruh kreditor, } \\
\text { baik kreditur konkuren } \\
\text { maupun kreditor penggagas } \\
\text { jaminan. Dengan catatan, } \\
\text { dianggap disetujui apabila } \\
\text { pihak yang setuju }>1 / 2 \\
\text { jumlah dari total jumlah } \\
\text { pihak yang berhak } \\
\text { memberikan suara dan } \\
\text { harus mewakili 2/3 dari } \\
\text { seluruh tagihan. }\end{array}$ \\
\hline
\end{tabular}

Selain hal-hal yang telah disebutkan, hal lainnya yang membedakan eksistensi perdamaian dalam penyelesaian perkara pailit di Pengadilan Niaga dengan perdamaian pada penyelesaian perkara perdata pada umumnya di Pengadilan Negeri adalah hasil dari perdamaiannya itu sendiri.

Di Pengadilan Negeri, perdamaian yang dicapai nantinya jelas akan menyelesaikan sengketa, memutus sengketa yang ada antara Tergugat dan Penggugat. Sementara di Pengadilan Niaga, karena perkara kepailitan ini adalah perkara volunteer yang mana tidak ada sengketa di dalamnya, maka hasil dari perdamaian yang dicapai ini nantinya akan mempermudah penyelesaian hutang debitur terhadap seluruh kreditor dan debitor tidak jadi dinyatakan pailit, sehingga perdamaian yang dicapai dalam hal ini dapat membuat masing-masing pihak dapat menjalankan usahanya dengan nyaman.

Konsekuensi Yuridis yang Membedakan antara Perdamaian Melalui Mediasi in Court dengan Perdamaian (accord) Dalam Pengketa Pailit dan PKPU Terkait dengan Kepastian Sebagai Tujuan Hukum. 
Tugas hakim dalam perkara perdata dikatakan bahwa hakim cukup menemukan kebenaran formil belaka, sedangkan dalam perkara pidana barulah hakim diwajibkan mencari dan menemukan kebenaran materil yang menyangkut nilai-nilai keadilan yang harus diwujudkan dalam peradilan pidana. Namun demikian, hakikat tugas hakim itu sendiri memang seharusnya mencari dan menemukan kebenaran materil untuk mewujudkan keadilan materiel. Kewajiban demikian berlaku, baik dalam bidang pidana maupun di lapangan hukum perdata. ${ }^{4}$

Perkara pailit ini adalah perkara volunteer yang berbeda dengan perkara contentiosa yang biasa diadili di Pengadilan Negeri. Dalam perkara pailit, tidak ada sengketa di dalamnya, putusan dari perkara pailit pun bersifat deklaratoir, hanya menentukan status. Namun, walaupun putusannya ini bersifat deklaratoir dan perkaranya merupakan perkara volunteer, tetapi ini nantinya akan mengarah pada sengketa, mengarah pada condemnatoir. Pada perkara contentiosa, menjadi suatu kewajiban bagi hakim untuk mengupayakan dan mengedepankan perdamaian melalui mediasi diawal persidangan, ataupun perdamaian dapat dilakukan diluar sidang dengan bantuan pihak ketiga diluar hakim mediator.

Dalam perkara kepailitan pun, penyelesaian sengketa yang ideal adalah terjadinya perdamaian (accord) antara Debitor dan Kreditor. Dalam hal ini memang dapat saja terjadi beberapa kemungkinan yakni Debitor membayar utangnya dengan cara menyicil, membayar utang sebagian sisanya dihapuskan, membayar utang pokok bunga dihapus dan berbagai alternative yang dapat dihasilkan berdasarkan kesepakatan kedua belah pihak. Bila hal ini dapat dicapai, tentu akan lebih menguntungkan kedua belah pihak. Bagi Debitor assetnya tidak perlu disita, perusahaan bisa berjalan terus, sementara bagi Kreditor piutang dapat dibayar kembali walaupun mungkin tidak sepenuhnya. Oleh karena itulah kehadiran perdamaian disini diperlukan, dianjurkan untuk dilaksanakan, agar nantinya tidak mengarah pada sengketa dan perkara antara

\footnotetext{
${ }^{4}$ www. kompasina.com/ kepastian hukum/ diakses pada tanggal 29 Maret 2017 Pukul 09.00
} WIB 
debitor dan kreditor dapat terselesaikan dengan baik berdasarkan win win solution.

Selanjutnya mengenai Putusan perdamaian dari perdamaian yang telah dikabulkan maupun ditolak dalam penyelesaian perkara pailit di Pengadilan Niaga ini tidak sama seperti putusan perdamaian yang ada di Pengadilan Negeri. Putusan Perdamaian tidak dituangkan ke dalam suatu akta (acta van dading) yang langsung berkekuatan hukum tetap (inkracht) dan tidak dapat lagi diajukan upaya hukum terhadapnya. Hasil dari upaya / rencana perdamaian yang dikabulkan maupun ditolak ini dituangkan ke dalam suatu putusan pengesahan perdamaian, atau disebut dengan istilah adalah Homologasi. Homologasi ini pun berbeda dengan Acta van Dading.

Putusan perdamaian di Pengadilan Umum pada dasarnya bersifat bebas, artinya tergantung pada para pihaknya, para pihak dapat memilih apakah mereka akan meminta hasil perdamaian yang telah dicapai tersebut untuk diputus secara formal agar dapat menghasilkan suatu akta atau tidak. Sementara putusan pengesahan perdamaian di Pengadilan Niaga dalam penyelesaian perkara pailit ini wajib diputus oleh majelis hakim (bukan oleh hakim pengawas, karena hakim pengawas hanya memimpin jalannya rapat perundingan atas rencana perdamaian). Selain itu, homologasi ini sendiri tidak secara langsung inkracht, layaknya putusan perdamaian di Pengadilan Negeri. Pihak yang tidak menerima putusan pengesahan perdamaian tersebut dapat mengajukan upaya hukum kasasi terhadap putusan tersebut sebagaimana diatur dalam Pasal 196. Permohonan kasasi ini dapat diajukan paling lambat delapan hari setelah putusan pengesahan perdamaian tersebut diucapkan.

Setelah pernyataan pailit pun masih dimungkinkan. Dengan kata lain, sekalipun Debitor sudah dinyatakan pailit oleh pengadilan, namun peluang bagi Debitor untuk melakukan perdamaian dengan Kreditor masih tetap terbuka, hal ini dinyatakan pada Pasal 144 UUKPKPU. Disini tampak bahwa pembentuk undang-undang melihat lebih jauh bahwa upaya perdamaian akan lebih baik 
bagi semua pihak daripada harus dinyatakan pailit yang berarti asset harus dijual untuk memenuhi kewajiban Debitor 5. Hanya saja dalam hal ini, pembentuk undang-undang juga memberi batas waktu agar ada kepastian hukum. Secara umum, berdasarkan pandangan dan pengalaman pribadi narasumber6, sejauh ini perdamaian yang dilaksanakan dalam rangka penyelesaian perkara pailit di Pengadilan Niaga cukup efektif dalam menyelesaikan perkara. Dengan adanya perdamaian, setiap perkara dapat diselesaikan dengan hasil lebih menguntungkan bagi para pihak. Debitor menjadi tidak pailit, dan tetap dapat menjalankan usahanya.

Seluruh Kreditor dapat menjalankan usahanya dengan tenang dan seluruh hutangnya terlunasi. Selain itu, pada umumnya pelaksanaan dari putusan pengesahan perdamaian ini sendiri, selalu dilaksanakan dengan baik, terlebih dalam hal perdamaian tersebut dikabulkan. Perdamaian yang disahkan akan berlaku bagi semua Kreditor yang tidak mempunyai hak didahulukan. Dalam hal pengesahan perdamaian telah memperoleh kekuataan hokum tetap, maka kepailitan berakhir. Kurator wajib mengumumkan perdamaian dalam Berita Negara RI dan paling sedikit dalam 2 (dua) surat kabar yang berskala Nasional.

Walaupun dalam praktik pelaksanaannya tidak dilakukan pengawasan terhadapnya, tetapi hampir dari seluruh perkara yang diakhiri dengan perdamaian yang dikabulkan oleh para pihaknya ini diselesaikan dengan baik dan tidak ditemukan peristiwa wanprestasi atas putusan perdamaian yang telah disepakati bersama tersebut. Wanprestasi terhadap putusan pengesahan perdamaian dalam hal ini sendiri terjadi apabila ada pihak yang tidak melaksanakan / memenuhi kewajiban sebagaimana ditentukan dalam putusan pengesahan perdamaian (homologasi) tersebut. Kemudian jika hal ini terjadi, maka tidak dapat serta merta diajukan permohonan untuk pelaksanaan eksekusi, sebagaimana dilakukan apabila terjadi wanprestasi terhadap putusan perdamaian yang diputus di Pengadilan Negeri pada umumnya.

${ }^{5}$ Sentosa Sembiring, Op. Cit., hlm 36.

${ }^{6}$ Hasil wawancara : pendapat pribadi Parwoto Wignjosumarto 
Upaya hukum yang dapat dilakukan apabila salah satu pihak wanprestasi terhadap putusan pengesahan perdamaian ini adalah permohonan untuk pembatalan putusan perdamaian. Akibat hukumnya, apabila kemudian dinilai bahwa alasan pengajuan permohonan pembatalan putusan perdamaian ini sesuai dan berdasar hukum, maka pembatalannya akan dikabulkan dan debitur kembali dinyatakan pailit. Sedangkan, jika dinilai bahwa alasan pengajuan permohonan pembatalan putusan perdamaian ini tidak berdasarkan hukum, maka permohonan pembatalan tersebut ditolak dan perdamaian tetap dilaksanakan.

Dapatlah disimpulkan bahwa baik perdamaian melalui lembaga mediasi maupun perdamaian dalam bentuk homologasi memberikan kepastian hukum kepada para pihak, karena adanya peradamaian menimbulkan konsekuensi hukum misal dalam sengketa perdata secara contentiosa, dengan ada acta van dading maka para pihak terikat dan tidak dapat mengajukan upaya hukum yang berbeda dengan konsep perdamaian dalam kepailitan.

Pada prinsipnya perdamaian memberikan perlindungan kepada para pihak yang berperkara, dan tujuan hukum berupa kepastian hukum dapat tercapai. Perkara menjadi lebih cepat terselesaikan dan Debitor dapat melanjutkan usahanya.

Dapat dikatakan bahwa pada hakikatnya kepastian hukum merupakan keadaan dimana perilaku manusia, baik individu, kelompok, maupun organisasi, terikat dan berada dalam koridor yang sudah digariskan oleh aturan hukum. Pengertian lainnya dari kepastian hukum adalah suatu kepastian tentang bagaimana peraturan perundang-undangan menyelesaikan masalah-masalah hukum, bagaimana peranan dan kegunaan lembaga lembaga hukum bagi masyarakat. Kepastian hukum juga dapat terwujud dalam keputusan pejabat yang berwenang yang menyangkut peristiwa tertentu. Dapat disimpulkan bahwa kepastian hukum adalah kepastian aturan hukum, bukan kepastian tindakan terhadap atau tindakan 
yang sesuai dengan aturan hukum. Oleh karenanya, dengan terjadinya perdamaian, kepastian hukum terwujud dengan adanya homologasi yang telah disepakati oleh kedua belah pihak yang lahir dengan perantara hakim di Pengadilan Niaga.

\section{PENUTUP}

1. Penerapan lembaga perdamaian melalui Perma No. 1 Tahun 2016 dengan cara mediasi tidak dapat diterapkan pada perkara kepailitan karena kepailitan termasuk dalam ranah volunteer sedangkan mediasi in court dilaksanakan pada perkara contentiosa. Oleh karenanya, perdamaian pada penyelesaian perkara pailit tidak dapat dilaksanakan di awal pemeriksaan perkara pailit di Pengadilan Niaga, karena perdamaian baru dapat diterapkan apabila status debitur sudah jelas sebagai pihak yang pailit.

2. Konsep Perdamaian yang dilaksanakan dalam rangka penyelesaian perkara pailit di Pengadilan Niaga tidak dapat dipersamakan begitu saja dengan konsep perdamaian yang dilaksanakan dalam rangka penyelesaian sengketa perdata pada umumnya di Pengadilan Negeri. Walaupun pokok/intinya adalah sama, yakni upaya untuk mendamaikan kedua belah pihak yang berperkara. Akan tetapi tujuan dari pelaksanaan perdamaian ini berbeda. Perdamaian dalam penyelesaian perkara pailit tidak dilaksanakan untuk memutus perkara, tetapi dilaksanakan untuk menyelesaikan perkara dengan cara yang lebih efektif dan menguntungkan bagi kedua belah pihak. Walaupun mediasi tidak dapat dilaksanakan dalam rangka mencapai perdamaian pada perkara pailit di Pengadilan Niaga, akan tetapi konsep win-win solution tetap terdapat dalam pelaksanaan perdamaian di Pengadilan Niaga ini yaitu yang mampu memberikan keuntungan yang seimbang bagi kedua belah pihak selaku pelaku usaha. Dengan dilaksanakannya perdamaian dalam penyelesaian perkara pailit, masing- 
masing pihak dapat melaksanakan usahanya dengan nyaman dan dapat memberikan kepastian hukum.

\section{Saran}

1. Para pihak yang bersengketa hendaknya dapat memahami dengan kesungguhan hati makna dari perdamaian dalam penyelesaian perkara.

2. Hakim maupun advokat harus berperan aktif untuk mendamaikan kedua belah pihak yang bersengketa agar tidak terjadi penumpukkan perkara di pengadilan

\section{DAFTAR PUSTAKA}

Fuady, Munir Arbitrase Nasional, Citra Aditya Bhakti, Bandung, 2000.

Mertokusumo, Sudikno, Bunga Rampai Ilmu Hukum, Penerbit Liberty, Yogyakarta, 1980.

Nating, Imran, Peranan dan tanggung Jawab Kurator dalam Pengurusan dan Pemberesan Harta Pailit, PT. Raja Grafindo Persada, cet 1, Jakarta, 2004

Sembiring, Sentosa, Hukum Kepailitan dan Peraturan Perundang-undangan yang Terkait Dengan Kepailitan, Nuansa Aulia, Bandung, 2006.

Yani, Ahmad dan Widjaja, Gunawan, Kepailitan, PT. Raja Grafindo Persada, Jakarta, 2004.

\section{Peraturan Perundang-undangan:}

Undang-undang No. 37 Tahun 2004 Tentang Kepailitan dan Penundaan Kewajiban Pembayaran Utang.

Undang-undang No. 48 tahun 2009 Tentang Kekuasaan Kehakiman

PerMa No. 1 Tahun 2016 Tentang Prosedur Mediasi di Pengadilan 


\section{Sumber Lain}

www. hukumonline.co.id/mediasi di pengadilan.html www. kompasina.com/ kepastian hukum/ 